Invited Articles

Pensar en Movimiento:

Revista de Ciencias del Ejercicio y la Salud ISSN 1659-4436

Vol. 14, No.2, pp. 1- 21

Cierre al 31 de diciembre, 2016

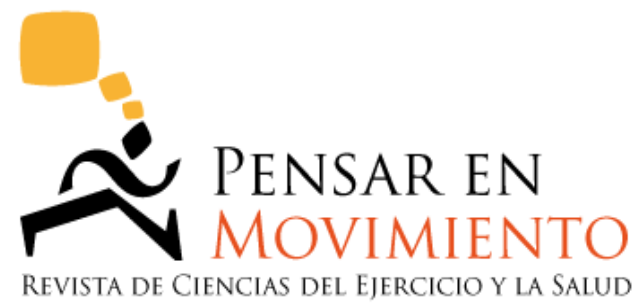

\title{
OCCUPATIONAL SEDENTARY BEHAVIOR AND SOLUTIONS TO INCREASE NON-EXERCISE ACTIVITY THERMOGENESIS ${ }^{1}$ \\ CONDUTA OCUPACIONAL SEDENTÁRIA E SOLUÇÕES PARA AUMENTAR A TERMOGÊNESE NÃO ASSOCIADA AO EXERCÍCIO
}

\author{
Haley M. Scott, M.Sc. ${ }^{2(B, C, D, E)}$; Tess N. Tyton, M.Sc. ${ }^{2(B, C, D, E)}$; \\ Craig A. Horswill, Ph.D. 2(B,C,D,E) \\ horswill@uic.edu \\ 2University of Illinois, Chicago, Illinois, USA \\ Original submission: 04/01/2016; resubmitted: 08/10/2016; \\ accepted: 09/05/2016; published: 10/31/2016 \\ Doi: http://dx.doi.org/10.15517/pensarmov.v14i2.23644
}

\begin{abstract}
Scott, H.M., Tyton, T.N., \& Horswill, C.A. (2016). Occupational Sedentary Behavior and Solutions to Increase Non-Exercise Activity Thermogenesis. PenSAR En MovimiEnTo: Revista de Ciencias del Ejercicio y la Salud, 14(2), 1-21. As the prevalence of obesity rises worldwide, researchers pursue explanations for the phenomenon, particularly those relevant to energy expenditure. Nonexercise activity thermogenesis, or NEAT, has been identified as an inconspicuous but appreciable component of total daily energy expenditure. Demands of certain occupations discourage time for planned physical activity and clearly diminish NEAT, and thereby contribute to sedentary behaviors that underlie increased adiposity. Prolonged sitting during the workday has specifically been identified as a risk factor for obesity and chronic disease independent of existing risk factors. Practical strategies have been launched by industry to increase NEAT during

${ }^{1}$ Original submission in English. Also available in the Spanish-translated version in this journal. -1 -

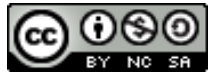

Esta obra está bajo una


the workday. Workstations that involve maintaining balance while sitting on an exercise ball, standing, pedaling while sitting, and walking at a treadmill desk have been developed to counter extended periods of sedentary behavior at work. While data are limited particularly for chronic benefits, the stations that promote the most movement - the pedaling and walking stations increase METS and energy expenditure more so than the other alternatives. The drawback to greater motion may be reduced attention to the desk job and therefore, reduced cognitive function; however, the data are inconsistent and the benefit for health may outweigh small distractions for some tasks at the desk.

Keywords: occupational health; physical inactivity; health; NEAT.

\section{RESUMO}

Conforme aumenta a prevalência da obesidade em todo o mundo, os pesquisadores buscam explicações para o fenômeno, em particular as que sejam relevantes ao gasto energético. Identificou-se que a termogênese não associada ao exercício, abreviada como NEAT, é um componente discreto, porém, ao mesmo tempo considerável do gasto energético diário total. As exigências de algumas ocupações são um obstáculo para dispor de tempo para a atividade física planificada e claramente reduzem a NEAT, o que contribui para as condutas sedentárias que provocam a adiposidade aumentada. Identificou-se que no tempo sentado prolongado durante 0 expediente como um fator de risco para a obesidade e as doenças crônicas, independentemente de outros fatores de risco existentes. Foram apresentadas algumas estratégias práticas para aumentar a NEAT durante o expediente: existem estações de trabalho que exigem manter 0 equilíbrio enquanto se trabalha sentado em una bola suíça (bola de exercício) ou trabalhar em pé, também outras nas quais se pedala sentado ou se camina em uma esteira incorporada à mesa de trabalho, para neutralizar os períodos prolongados de trabalho sedentário no escritório. Ainda que existam poucos dados sobre os benefícios crônicos destas estações, aquelas que promovem mais movimento-as estações de pedalada ou de caminhada-aumentam os METs e o gasto energético total mais que as outras alternativas. A desvantagem de mover-se mais é que poderia haver uma diminuição na atenção do trabalho de escritório e, portanto, uma diminuição no funcionamento cognitivo; porém, os dados não são consistentes e pode ser que o benefício para a saúde seja igual ou maior que a desvantagem de experimentar algumas pequenas distrações durante as tarefas de escritório.

Palavras-chaves: Metabolismo; gasto energético; saúde ocupacional.

The present-day worldwide obesity crisis in industrially and technologically developed societies can be explained by a surplus of energy consumed compared to the amount of energy expended. The difference or balance between total daily energy expenditure, or TDEE, and the daily energy intake determines whether a human maintains or changes body weight. While efficiency of storage and of calorie usage can be debated as contributing factors, the laws of thermodynamics dictate that if energy intake exceeds output then weight gain will occur.

- 2 -

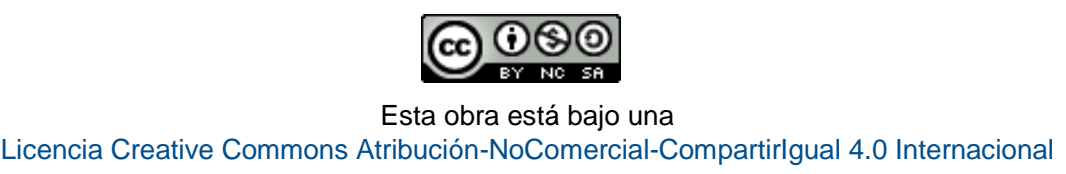


It is unclear which side of the energy balance equation has changed more dramatically in recent decades to arrive at the current healthcare predicament. Many would argue, though, that sedentary lifestyle is indeed a major factor. The warning, "sitting is the new smoking" embodies the concern (Mayo Clinic, 2014). Advances in technology and business-world objectives of everincreasing productivity further promote inactivity as nearly all means of conducting business can be done for prolonged periods of the workday without leaving one's desk.

The objectives of this brief review are to a) define and characterize components of our daily energy expenditure; b) summarize the impact of sedentary lifestyle and prolonged sitting on risk factors of obesity and chronic disease, and c) identify and describe the impact of alternative workstations that may increase non-exercise activity thermogenesis, or NEAT, and promote movement while still allowing the worker to accomplish demands for the daily job. For the last objective, the acute and chronic effects of active workstations will be summarized as will the effects on cognitive function relevant to desk-job productivity.

The literature supporting this review was obtained from searches on PubMed and Google Scholar. The key words and phrases used included the following: calorie expenditure, cognitive, desk, energy-expenditure, energy-expenditure methodology, fidgeting, health, health risk factors, inactivity, non-exercise activity thermogenesis, occupational sitting, oxygen consumption, pedal workstation, physical inactivity, resting metabolic rate, risk factors, seated metabolic rate, sedentary, sedentary behavior, sitting, sitting metabolic rate, stability ball work station, standing, standing workstation, standing desk, thermogenic effect of food, total daily energy expenditure, workstation, workstation treadmill. For the sections on Prolonged Sitting and Workstations, the literature searches extended back to about 2000.

\section{Total Daily Energy Expenditure}

The energy expended by humans in a 24-h period defines TDEE. Figure 1 presents the components of TDEE as three distinct calorie-demanding processes: basal metabolism, the thermogenic effect of food (TEF), and physical activity (Levine 2005). Basal metabolic rate (BMR) is the energy used for cell, tissue, and organ homeostasis at rest. BMR contributes the largest proportion to TDEE, between 60 and $75 \%$, and is largely dependent on the mass of the most metabolically active tissue, the lean tissue (Hill, Melby, Johnson, \& Peters, 1995). Therefore, BMR is influenced by and can be predicted from age, height, body mass, and sex. TEF is the facultative and obligatory cost of digestion and metabolism of meals, and contributes the least at $\sim 10 \%$ of TDEE. It appears to be largely unchangeable except for diet composition manipulation (Hill et al., 1995) but even that would have relatively little impact on TDEE (Hill et al., 1995). Physical activity accounts for the remaining 15 to $30 \%$, it is the most variable, and can be most influenced by our behavior compared to the resilience of BMR and TEF. 


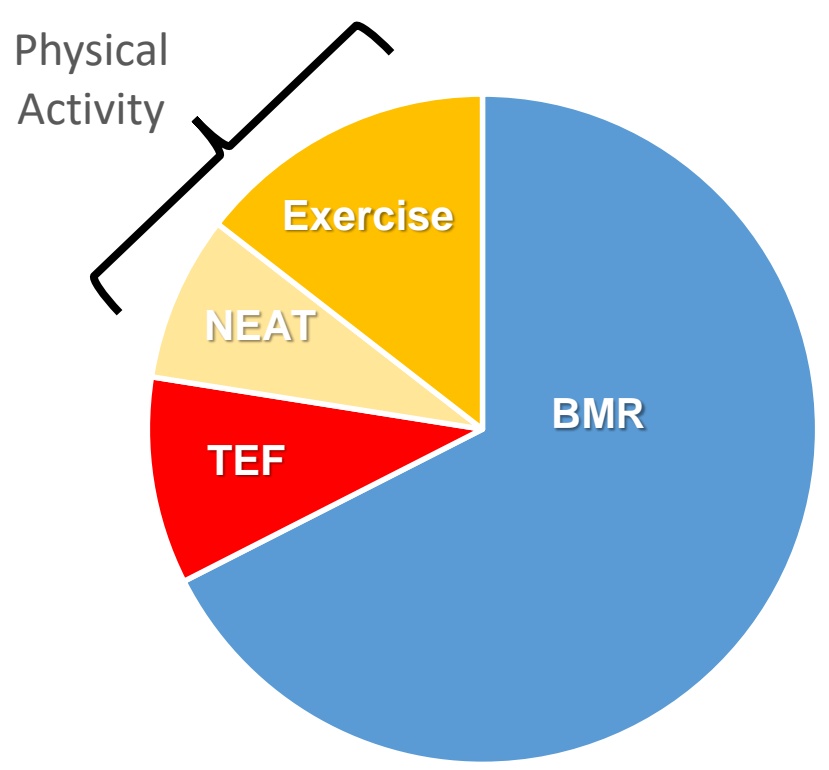

Figure 1. Components and approximate proportions of total daily energy expenditure. Source: The Authors.

In addressing TDEE and sedentary lifestyle, the physical-activity component of TDEE has been further dissected into planned activity, i.e. exercise, and NEAT, which can be considered movement that doesn't reach a threshold for fitness but from a cumulative standpoint, could demand appreciable calories during the day. Spontaneous activity would be considered a part of NEAT. Early work to separate exercise and NEAT suggested that fidgeting, a form of NEAT, could contribute expenditures of up to $800 \mathrm{kcal}$ per day (3350 KJ) (Ravussin, Lillioja, Anderson, Christin, \& Bogardus, 1986). Using a room calorimeter and motion detectors, Ravussin and colleagues were able to dissect the components of total daily energy expenditure in 177 subjects who remained in the chamber for $24 \mathrm{~h}$ (Ravussin et al., 1986). They attributed an average of $8.7 \%$, with a range of 3.9 to $16.6 \%$, of the TDEE to spontaneous movement based on oxygen consumption and motion assessment. A cumulative effect of NEAT over a period of years could help explain why some individuals remain relatively lean and at normal body mass without engaging in formal exercise or restricting caloric intake (Johannsen et al., 2008; Ravussin et al., 1986; Levine, 2002).

Interrelationships exist among the components making up TDEE such that changing one component may affect another. Hill et al. (1995) described the theoretical effects of planned exercise impacting body mass on an initial reduction of fat mass if compensation does not occur; in other words, when exercisers don't consume more energy. In time, once the body hits the 
settling point described by Hill et al. (1995), continued energy deficit from exercise will result in loss of fat-free mass, which would reduce BMR and TDEE. In practice, this relationship may not operate as expected and could be complicated by other factors such as race (DeLany et al 2014). Reducing energy intake, i.e., dieting, would lower daily TEF and could also result in decreased daily physical activity and total daily energy expenditure (Redman et al., 2009). Blaak, Westerterp, Bar-Or, Wouters, \& Saris, (1992) and Racette, Schoeller, Kushner, \& Neil, (1995) showed that obese individuals undergoing a planned exercise program increase spontaneous activity and possibly TDEE because TDEE in these individuals increased beyond that predicted for the addition of the formal exercise.

Results from other studies are somewhat mixed with no decreases in spontaneous activity and energy expenditure as a result of engaging in an exercise program (Willis et al 2014) or an apparent decrease because of the lack of weight reduction (Thivel, Chaput, Adamo, \& Goldfield, 2014). The effect of a planned exercise program on spontaneous energy expenditure may depend on the population studied, i.e. lean vs. obese or older vs. younger. In addition, the type of exercise program, i.e. aerobic vs. resistance training may have a different effect on energy expenditure in spontaneous activity (Drenowatz, Grieve, \& DeMello, 2015). It is unknown whether the reverse is true, that increased activities that increase NEAT might also increase one's engagement in planned exercise.

Regardless, the contribution of NEAT to TDEE is intriguing enough that opportunities to increase NEAT are being explored in research and offered in the workplace that has otherwise been a major factor in promoting inactivity. A summary of that research is addressed in the last section of this review. Over the last two decades, the lack or reduction of daily physical activity is increasingly of concern for health and mortality and has resulted in the medical community united in recommending standard for exercise and health (Pate et al., 1995; Haskell et al 2007).

\section{Prolonged Sitting and Health Risks}

Sitting as a Sedentary Behavior. The experts continue to debate and refine the definition of sedentary behavior to distinguish it from physical inactivity, i.e. failure to achieve the recommended volume of exercise per week for fitness and health benefits. Sedentary activities are those during waking hours that elicit a metabolic rate of 1.0 to 1.5 in metabolic equivalents (METS) according to the Compendium of Physical Activities (Ainsworth et al., 2000; Pate, O'Neill, \& Lobelo, 2008). The Sedentary Behaviour Research Network (2012) added position to the definition to help qualify the term: behavior that elicits metabolism $\leq 1.5$ METS in a seated or reclined position. The debate is complicated by the observation that health benefits can be gained by behaviors that fail to exceed the METS limit in either definition but at least surpass the category of seated position, i.e. standing (Gibbs, Hergenroeder, Katzmarzyk, Lee, \& Jakicic, 2015). For the purposes of this review, prolonged sitting at a desk with minimal movement is considered sedentary behavior. 
During waking hours, the average person spends over half of the day engaged in sedentary behaviors (Matthews et al., 2008) and sitting is one of the most common forms. Sitting occurs while commuting, during most meetings, while doing selected leisure activities such as watching television or computer games, and at the desk station. Based on epidemiological studies, the volume of time spent sitting increases with age (Matthews et al., 2008). While it is possible to reduce time in sedentary behaviors by participating in leisure activities requiring movement, many people do not have the option to reduce time spent sitting because of work obligations.

Occupational Sitting. Careers such as in administration, transportation, and technology require employees to spend the majority of the workday at a desk with minimal movement. The term 'occupational sitting' has been coined to describe such inactive behavior. Examples of the magnitude are seen in studies of behaviors of workers. Employees at a call center spent an average of $6.6 \mathrm{~h}$ of the workday deskbound while another study found a similar duration $6.2 \mathrm{~h}$ of total time sitting on the job (Ryde et al., 2014; Thorp et al., 2012). Of further concern, for men a sedentary work environment fosters involvement in physically inactive leisure time activities outside of work (Gimeno et al., 2009). Combining sedentariness at work with sedentary leisure time compounds overall physical inactivity on a daily basis. Maintaining low energy expenditure throughout the majority of the day has implications for promoting overweight and obesity, accompanied by an increased risk for chronic disease over time (See Table 1).

Health Risks. While it is generally accepted that physical inactivity has implications for various health risks and all-cause mortality, an expanding amount of research focuses on the health risks associated with occupational sitting independent from general inactivity. General physical inactivity, such as the absence of regular exercise, is clearly associated with the development of obesity, coronary artery disease, type 2 diabetes, various types of cancers, and premature mortality (Lee et al., 2012). Those who work in careers that require being sedentary for the majority of work hours may be doing additional harm to their bodies than realized. Contrary to the assumption that regular exercise at the beginning or end of the day is sufficient to undo the damage of the day's physical inactivity, at least one study suggests this approach will not offset the ill effects of prolonged sedentary behavior including occupational sitting (Matthews et al., 2012). Additionally, in a study showing $7 \%$ of deaths were due to prolonged sitting, undergoing 30 minutes of moderate exercise per day (the ACSM recommendation) offered no reduction in risk, i.e., the hazard ratio was $\geq 1$, if an individual sat between 8-to-11 h of the day (Van der Ploeg, Chey, Korda, Banks, \& Bauman, 2012).

The health risks of occupational sitting include being overweight and obese. A summary of several large scale studies supporting this are seen in Table 1. The work of Lin, Courtney, Lombardi, \& Verma, (2015) and Eriksen, Rosthøj, Burr, \& Holtermann (2015) show the development of obesity linked to hours of sitting, indicating 
Table 1

Summary of studies on health risks associated with occupational sitting

\begin{tabular}{|c|c|c|c|c|c|c|}
\hline Health Risk & Study & Design & Sample & Variable & $\begin{array}{l}\text { Occupational } \\
\text { Sitting }\end{array}$ & Results \\
\hline \multirow{3}{*}{$\begin{array}{l}\text { Overweight/ } \\
\text { Obesity }\end{array}$} & $\begin{array}{l}\text { Mummery et } \\
\text { al, } 2005\end{array}$ & $\begin{array}{l}\text { Cross- } \\
\text { sectional }\end{array}$ & $n=1,579$ & $\mathrm{BMI} \geq 25$ & $>6$ hours/day & $\begin{array}{l}\text { Overweight \& obesity } \\
\text { associated with } \\
\text { occupational sitting time in } \\
\text { men }\end{array}$ \\
\hline & $\begin{array}{l}\text { Lin et al, } \\
2015\end{array}$ & $\begin{array}{l}\text { Longitudinal } \\
\text { - } 8 \text { year } \\
\text { study }\end{array}$ & $n=5,285$ & BMI & Avg: $3 \mathrm{hr} /$ day & $\begin{array}{l}\text { Increased sitting time } \\
\text { significantly associated } \\
\text { with increased BMI }\end{array}$ \\
\hline & $\begin{array}{l}\text { Eriksen et } \\
\text { al, } 2015\end{array}$ & $\begin{array}{l}\text { Longitudinal } \\
\text { - } 5 \text { year } \\
\text { study }\end{array}$ & $n=4,732$ & BMI & $\begin{array}{l}\text { Avg: } \geq 25 \\
\text { hr/week }\end{array}$ & $\begin{array}{l}\text { Association between } \\
\text { occupational sitting time } \\
\text { and increased BMI in } \\
\text { women }\end{array}$ \\
\hline \multirow{3}{*}{$\begin{array}{l}\text { Cardio- } \\
\text { vascular } \\
\text { Disease }\end{array}$} & $\begin{array}{l}\text { Katzmarzyk } \\
\text { et al, } 2009\end{array}$ & $\begin{array}{l}\text { Longitudinal } \\
\text { - } 12 \text { year } \\
\text { study }\end{array}$ & $n=17,013$ & $\begin{array}{l}\text { Death from CV } \\
\text { disease }\end{array}$ & $\begin{array}{l}\text { Total daily } \\
\text { sitting time }\end{array}$ & $\begin{array}{l}\text { Dose-response between } \\
\text { sitting time and death from } \\
\text { CV disease }\end{array}$ \\
\hline & $\begin{array}{l}\text { Warren et } \\
\text { al, } 2010\end{array}$ & $\begin{array}{l}\text { Longitudinal } \\
\text { - } 21 \text { year } \\
\text { study }\end{array}$ & $n=7,744$ & $\begin{array}{l}\text { Death from CV } \\
\text { disease }\end{array}$ & $\begin{array}{l}>23 \mathrm{hr} / \text { week } \\
\text { commuting/ } \\
\text { watching TV }\end{array}$ & $\begin{array}{l}64 \% \text { increased risk of } \\
\text { death from CV disease }\end{array}$ \\
\hline & $\begin{array}{l}\text { Altieri et al, } \\
2004\end{array}$ & $\begin{array}{l}\text { Case-control } \\
\text { - } 4 \text { year } \\
\text { study }\end{array}$ & $n=507$ & $\begin{array}{l}\text { Incidence of } \\
\text { acute } \\
\text { myocardial } \\
\text { infarction }\end{array}$ & $\begin{array}{l}\text { Level of } \\
\text { occupational } \\
\text { physical } \\
\text { activity }\end{array}$ & $\begin{array}{l}\text { Inverse association } \\
\text { between occupational } \\
\text { physical activity and } \\
\text { incidence of acute } \\
\text { myocardial infarction } \\
\end{array}$ \\
\hline \multirow{2}{*}{$\begin{array}{l}\text { Metabolic } \\
\text { Dysfunction }\end{array}$} & $\begin{array}{l}\text { Hu et al, } \\
2003\end{array}$ & $\begin{array}{l}\text { Longitudinal } \\
\text { - } 12 \text { year } \\
\text { study }\end{array}$ & $n=14,290$ & $\begin{array}{l}\text { Incidence of } \\
\text { type } 2 \text { diabetes }\end{array}$ & $\begin{array}{l}\text { Light } \\
\text { occupational } \\
\text { physical } \\
\text { activity }\end{array}$ & $\begin{array}{l}\text { Incidence of type } 2 \\
\text { diabetes was highest in } \\
\text { those with lowest levels of } \\
\text { occupational physical } \\
\text { activity }\end{array}$ \\
\hline & $\begin{array}{l}\text { Chu \& } \\
\text { Moy, } 2013\end{array}$ & $\begin{array}{l}\text { Cross- } \\
\text { sectional }\end{array}$ & $n=686$ & $\begin{array}{l}\text { Incidence of } \\
\text { factors } \\
\text { associated with } \\
\text { metabolic } \\
\text { disease }\end{array}$ & $\begin{array}{l}\text { Low levels of } \\
\text { occupational, } \\
\text { transport, and } \\
\text { household } \\
\text { physical activity }\end{array}$ & $\begin{array}{l}\text { Low levels in all areas of } \\
\text { physical activity associated } \\
\text { with higher odds of } \\
\text { metabolic disease }\end{array}$ \\
\hline \multirow{3}{*}{ Cancer } & $\begin{array}{l}\text { Thune et } \\
\text { al, } 1997\end{array}$ & $\begin{array}{l}\text { Longitudinal } \\
\text { - } 13 \text { year } \\
\text { study }\end{array}$ & $n=25,624$ & $\begin{array}{l}\text { Incidence of } \\
\text { breast cancer }\end{array}$ & $\begin{array}{l}\text { Level of work } \\
\text { phys. activity - } \\
\text { (sedentary to } \\
\text { manual labor) }\end{array}$ & $\begin{array}{l}\text { Higher levels of } \\
\text { occupational physical } \\
\text { activity associated with } \\
\text { lower risk of breast cancer }\end{array}$ \\
\hline & $\begin{array}{l}\text { Levi et al, } \\
1999\end{array}$ & $\begin{array}{l}\text { Case-control } \\
\text { - } 5 \text { year } \\
\text { study }\end{array}$ & $n=620$ & $\begin{array}{l}\text { Risk of breast } \\
\text { cancer }\end{array}$ & $\begin{array}{l}\text { Occupational } \\
\text { sitting - } \\
\text { "mainly sitting" }\end{array}$ & $\begin{array}{l}\text { Highest risk of breast } \\
\text { cancer associated with } \\
\text { highest level of } \\
\text { occupational sitting }\end{array}$ \\
\hline & $\begin{array}{l}\text { Tavani et } \\
\text { al, } 1999\end{array}$ & $\begin{array}{l}\text { Case-control } \\
\text { - } 5 \text { year } \\
\text { study }\end{array}$ & $n=5,379$ & $\begin{array}{l}\text { Risk of colon } \\
\text { and rectal } \\
\text { cancer }\end{array}$ & $\begin{array}{l}\text { Occupational } \\
\text { sitting - } \\
\text { "mainly sitting" }\end{array}$ & $\begin{array}{l}\text { Occupational physical } \\
\text { activity protective against } \\
\text { colon cancer }\end{array}$ \\
\hline
\end{tabular}

Source: The Authors.

$-7-$

Esta obra está bajo una 
some element of cause-and-effect beyond merely an association. Extended periods of minimal calorie burning, such as sitting, increases likelihood of an energy surplus and onset of obesity in the individual. The study conducted by Eriksen and colleagues (2015) revealed that sitting for an average of 25 or more hours per week was associated with an increased BMI over a 5-year period in women. The combination of being overweight or obese and sitting motionless for long periods of the day potentially compound the health risks for individuals.

Being overweight or obese increases the risk of developing cardiovascular disease. A direct relationship between occupational sitting and development of cardiovascular disease independent of adiposity is not completely clear; however, an association has been identified (Altieri, Tavani, Gallus, \& La vecchia, 2004; Warren et al, 2010). The risk of developing cardiovascular disease or suffering from a related condition is increased with excess sitting time (Table 1). A study conducted by Altieri and colleagues (2004) determined that a greater amount of occupational sitting increased the risk of having an acute myocardial infarction over a 4-year span. These researchers found that prolonged sitting for work accounted for $11 \%$ of acute myocardial infarctions.

Metabolic dysfunction, including metabolic syndrome, is another outcome of excess energy storage, adiposity, and inactivity. Insulin resistance, elevated blood glucose, high cholesterol, and hypertension are components of the dysfunction and precede Type 2 diabetes and cardiovascular disease. Excess sitting including occupational sitting has been linked to metabolic dysfunction. A 12-year longitudinal study conducted in Finland found that the incidence of type 2 diabetes is much lower in those who are more physically active at work compared to those who are mainly sedentary (Hu et al., 2003). This association was evident following adjustment for sedentary behavior during commute as well as leisure time. While it is unclear whether this is a causal relationship, the results of this study indicate a need for decreasing the amount of time being sedentary while at work.

The effect of sitting on the development of various types of cancer has recently been examined. Although the data are relatively scarce, an association has been made for occupational sitting and breast and colon cancer. A 13-year longitudinal study conducted by Thune, Brenn, Lund, \& Gaard (1997) revealed that higher levels of physical activity at work are associated with a decreased risk of breast cancer. Levi, Pasche, Lucchini, \& La Vecchia (1999) found that greater volumes of time in occupational sitting were associated with the highest risk of developing breast cancer among their sample. The risk of colon cancer, but not rectal cancer, is also decreased with increasing levels of occupational physical activity (Tavani et al., 1999). Overall, long periods of sedentary behavior while at work appear to be a hazard to health and a catalyst to obesity and metabolic diseases.

\section{Workstations}

With workers desk-bound and potentially spending two-thirds of their day sitting, there is a pressing need to incorporate non-exercise activity or planned physical activity into their lives 
(Ryde et al., 2014). In considering alternatives to the typical sitting workstation to increase energy expenditure and movement during work hours, it is important that the activity does not interfere with work productivity. In situations in which prolonged sitting is necessary to accomplish job objectives, it may be beneficial to break up prolonged sitting time with walking breaks or intermittent activity/movement alternatives to use during work hours.

Currently, four alternative workstations exist to promote energy expenditure and movement. These include: 1) sitting on a stability ball, 2) standing or adjustable sit-stand desk, 3) pedal device attached underneath the desk, and 4) treadmill walking desk. We refer the reader to Tudor-Locke, Schuna, Frensham, \& Proenca (2014) for a thorough summary of the terminology and critical aspects of workstations, but for the purposes of this review, we'll classify sitting on the stability ball and standing at a desk as reactive or static. The movements that occur with these alternatives are mainly due to weight shifting or postural changes in a fixed position. Overall, reactive workstations are very practical and widely available. However, they might not induce enough movement to significantly raise energy expenditure or derive health benefits. We classify workstations that involve pedal devices and treadmill walking desks as proactive or dynamic. These alternatives facilitate rhythmic movements at variable intensities. While proactive workstations elicit more movement and a higher energy expenditure, the cost and practicality may be limiting. In addition, because the physical effort is deliberate, redirected mental attention could reduce work productivity. The remainder of this review will address what the research shows about the acute and chronic health benefits, along with cognitive performance, when using the four primary alternative workstations.

Acute Responses to Alternative Workstations. By increasing movement through alternative workstations, acute physiological responses are expected for energy expenditure, heart rate, and blood pressure. Acute responses are easily measured and may explain why greater amounts of research exist for immediate effects than chronic effects. However, the cumulative effects of daily acute responses presumably would contribute to chronic changes that alter risk of diseases.

Energy Expenditure. The increase in daily energy expenditure through alternative workstations helps offset daily energy intake and cumulatively benefits the individuals in the long term. Evidence indicates that the rate of energy expenditure varies depending on the category of the workstation alternative. This can be seen in Figure 2, which summarizes the mean values in the literature for energy expenditure at various workstations. The pattern suggests that generally, while reactive workstations elevate metabolism, the expenditure remains lower than proactive workstations. In one case, the rate of energy expenditure while using a reactive workstation did not rise above that of merely sitting at a workstation (Speck and Schmitz 2011). 


$$
\bullet A \bullet B \bullet C \bullet D \bullet E \bullet F \bullet G \bullet H \bullet I \bullet J
$$

\section{$\mathrm{EE}, \mathrm{kcal} / \mathrm{min}$}

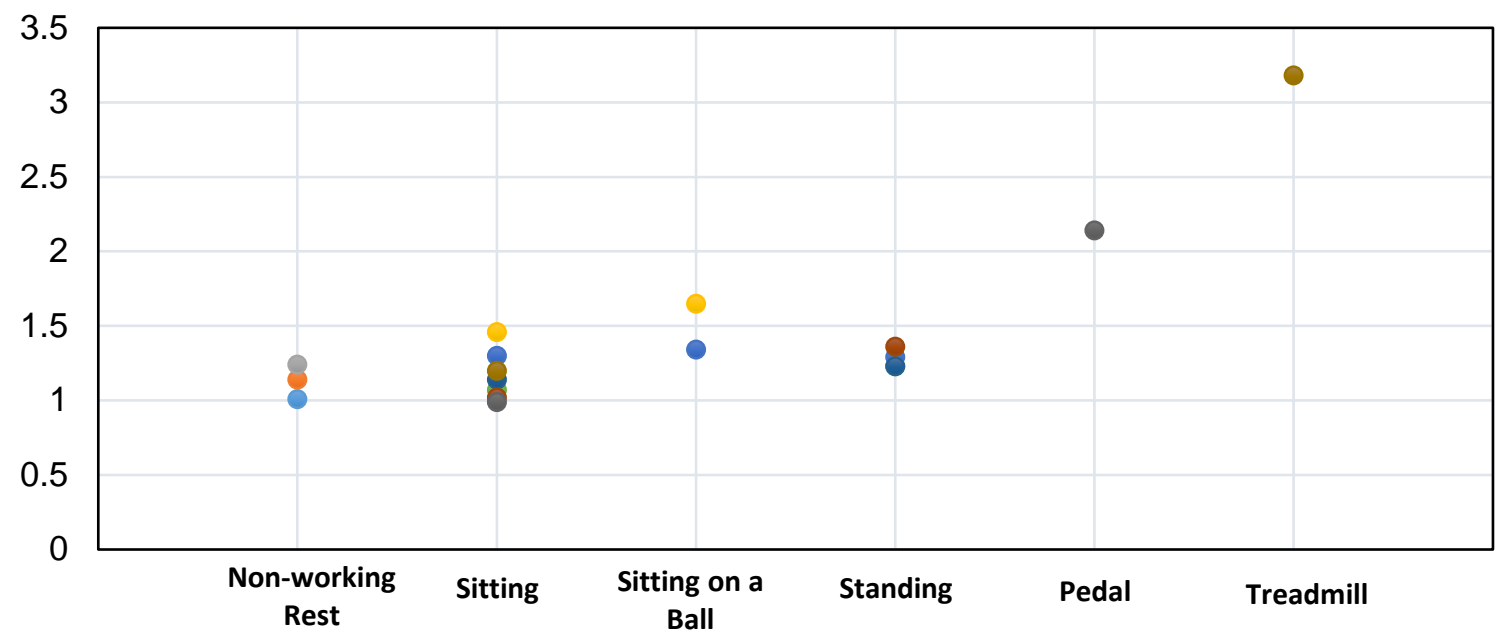

Workstation Category

Figure 2. Summary of literature values for mean rate of energy expended at traditional and alternative workstation alternatives. Adapted and updated from Tudor-Locke et al., 2014. References: (A) Wright et al., 2015 [normal weight]; (B) Wright et al., 2015 [overweight]; (C) Wright et al., 2015 [obese]; (D) Dickin et al., 2015; (E) Speck et al., 2011; (F) Benden et al., 2014 [Fall]; (G) Benden et al., 2014 [Spring]; (H) Reiff et al., 2012; (I) Carr et al., 2014; (J) Levine et al., 2007. Source: The Authors.

Examining the stability ball sitting further, slight increases in energy expenditure may occur due to the compliant surface and reactive movements to maintain balance. For example, Dickin, Surowiec, \& Wang (2015) measured energy expenditure of workers on a flat chair, cushioned chair, and a stability ball. Average energy expenditure was calculated based on oxygen consumption and carbon dioxide production during three 10-minute tasks. Results showed a difference in energy expenditure when comparing the flat chair $(1.46 \pm 0.25 \mathrm{kcal} / \mathrm{min}[6.1 \pm 1.0$ $\mathrm{KJ} / \mathrm{min}])$ and stability ball $(1.65 \pm 0.20 \mathrm{kcal} / \mathrm{min}[6.9 \pm 0.8 \mathrm{KJ} / \mathrm{min}])$. Use of the stability ball and the cushion promoted greater energy expended compared to the flat surface chair by $10.4 \%,(p=0.01)$ and $9.6 \%(p=0.03)$, respectively, indicating that the yielding surface may be an effective means to forcing muscle to contract. In addition, studies of standing desk question their value specific to energy expenditure as small increases or no statistically significant change has been reported in children (Benden, Zhao, Jeffrey, Wendel, \& Blake, 2014) and adults (Reiff, Marlatt, \& Dengel, 2012; Speck and Schmitz, 2011). Nonetheless, Benden et al. (2014) and Reiff et al (2012) explained the practicality of implementing the standing desks into classrooms. Despite relatively small increases in energy expenditure, the modest activity of standing by children and collegeage students may be beneficial in the long term due to the accumulation effect over a lifetime. In 
contrast, Speck and Schmitz (2011) reported no differences in metabolism during computer performance at alternative workstations (stability ball or standing) in inactive adults who were generally overweight (BMI average 27) questioning whether these would contribute to NEAT and the related health benefits in all individuals.

In contrast to reactive alternative workstations, proactive alternative workstations clearly elevate rates of energy expenditure. Carr et al. (2014) found that energy expenditure doubled from merely sitting to pedaling while sitting. Subjects pedaled for 30 minutes and burned an average of $69 \pm 24 \mathrm{kcal}(288.7 \pm 100 \mathrm{KJ} / \mathrm{min})$. Data from Levine \& Miller (2007) for a treadmill workstation led to the conclusion that walking at just over $1 \mathrm{mph}$ while working would elevate energy expenditure $100 \mathrm{kcal}$ per hour $(418 \mathrm{KJ} / \mathrm{h})$ compared to sitting. Active alternative workstations allow workers to engage in physical activity at their own intensity or intermittently. The higher the intensity and longer the duration, the more energy is expended.

Cardiovascular Responses. The cardiovascular system is negatively affected by prolonged inactivity including sitting. Acutely increasing heart rate and blood pressure with physical activity is beneficial for strengthening the heart, increasing blood flow, and promoting vessel dilation. Carr et al. (2014) tested physiological effects of actively sitting with a pedal device underneath the desk. This study found that heart rate increased significantly between sedentary sitting and proactive pedal sitting ( $75 \pm 12$ vs. $89 \pm 11 \mathrm{bpm})$. Systolic blood pressure also significantly increased $(109 \pm 11$ vs. $122 \pm 20 \mathrm{mmHg}$ ). Whether an alternative active workstation provides enough stimulus for adaptations over time, i.e., lowered resting heart rate and blood pressures will be addressed in the next section.

Prolonged sitting at a desk job has also been identified as a risk of deep vein thrombosis (Dunstan, Howard, Healy, \& Owen, 2012a). More commonly thought of as a health concern for elderly and those doing prolonged air travel, the case study of a 32-y old male who spent extensive time motionless at a computer station brought the issue to light (Beasley, Raymond, Hill, Nowitz, \& Hughes, 2003). Subsequent experimental research identified hematopoetic changes and the expression of skeletal muscle genes that could contribute to the development of thrombosis as a result of physical inactivity brought on by prolonged sitting or simulation of prolonged sitting (Howard et al 2013; Zderic and Hamilton 2012). Breaking up the workstation sitting by 2 min of walking at $\sim 2 \mathrm{mph}$ three times an hour reduced the development of blood factors that promote pro-coagulation and the risk of thrombosis (Howard et al 2013). A case study of one individual and analyses of the animal tissue showed that subsequent bouts of physical activity did not reverse the suppression of lipid phosphate phosphatase-1, which would have a protective effect by degrading factors that promote thrombosis (Zderic and Hamilton 2012). This again suggests that intermittent activity to break up prolonged sitting is important, in this case to prevent hemostasis and risks of thrombosis.

Metabolic Responses. Low-level activity and interruptions to sitting at workstations may help increase glucose tolerance. By recruiting motor units for muscle contraction even at light 
intensities, it is possible that tissue sensitivity to insulin can be enhanced, which would explain reports of acute improvement in glucose tolerance (Dunstan et al., 2012b; Dempsey et al., 2016; Healy et al 2007). Whether this reduces the risk of Type 2 diabetes remains to be seen.

Chronic Responses. Long-term prospective studies on the effects of alternative workstations are limited. Chronic benefits of increased NEAT or physical activity with alternative workstations include weight loss, improvements in the cardiovascular system, lower blood pressure, reduction cholesterol levels, and reduced risk of diseases associated with sedentary lifestyle. This assumes that workers would engage in the workstation activity throughout the majority of, if not the entire workday.

Weight Loss. Obesity occurs with a negative energy balance, with as little as $100 \mathrm{kcal}$ (418 $\mathrm{KJ}$ ) excess intake per day if the imbalance is consistently applied (Hill, 2003). The Center for Disease Control explains that a moderate amount of physical activity is roughly equivalent to physical activity that expends approximately $150 \mathrm{kcal}$ per day $(627 \mathrm{KJ} /$ day $)$, or 1,000 kcal per week (4 $180 \mathrm{KJ} /$ week) (Health and Human Services, 2008). As previously discussed and summarized in Figure 2, energy expenditure increases when using alternative workstations compared to the rate at a seated workstation. Even slight elevations in expenditure with some of the static alternative workstations (Reiff et al., 2012; Dickin et al., 2015), could compound over months and years to contribute to weight control benefits. We will start with the theoretical outcomes before looking at empirical finding.

Using expenditure for sitting on a stability ball, the added expense of about $0.55 \mathrm{kcal}$ per minute $(2.3 \mathrm{KJ} / \mathrm{min})$ compared to merely sitting would compound to 260 additional kcal per 8-hour workday (1088 KJ) (Faries, Bartholomew, \& McCallister, 2011). This increase could allow workers to expend 1,300 extra kcal per week (5 $439 \mathrm{KJ})$. Dickin et al. (2015) suggested that even though there is a slight elevation in calories expended for the stability ball sitting at work, over the course of a year it is possible to burn 1.8 to $2.3 \mathrm{~kg}$ of fat. Using data in college-age students, Reiff et al. (2012) extrapolated to middle-school-age children and speculated that young students would expend an additional $114 \mathrm{kcal}$ per school day (477 KJ), or 20,461 kcal (85 $609 \mathrm{KJ})$ per year based on average desk time in middle school. This could translate to a potential weight loss of about $2.6 \mathrm{~kg}$ per year from standing desks. The relatively minor acute effects of reactive movement workstations may provide chronic health benefits when compared to sedentary sitting, if the behavior is consistently applied.

Proactive alternative workstations showed even higher rates of energy expenditure, which could further facilitate weight loss or control with regular use and if workers do not compensate by ingesting more energy or becoming less active outside of work. The pedal workstation study done by Carr and colleagues (2014) showed an increase of $68 \mathrm{kcal}(285 \mathrm{KJ})$ expended per hour. The authors believe this effect may be adequate to reduce the risk of diabetes by facilitating weight loss and improved glucose and insulin intolerance (Carr et al., 2014). Similarly, Levine et al. (2007) showed that with treadmill walking, energy expenditure could be increased by $119 \mathrm{kcal}$

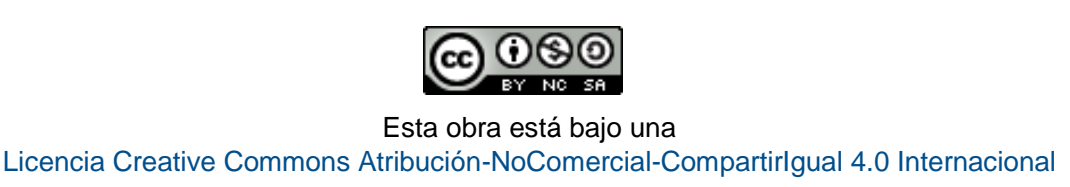


(498 KJ) per hour or $952 \mathrm{kcal}(3983 \mathrm{KJ})$ per workday. For obese individuals, treadmill walking at work for two to three hours per day could equate to a weight loss of 20 to $30 \mathrm{~kg}$ a year if other components of energy balance were constant (Levine et al., 2007).

The empirical data while showing benefits, indicates the projections are overpromising. In the lone longitudinal study, Koepp et al. (2013) conducted a 1-year observation of employees in otherwise sedentary jobs. Employees had treadmill desks installed to use for a year and were instructed to walk on the treadmill while performing all normal work activities. With the treadmilldesk intervention, the employee average weight loss was $1.4 \mathrm{~kg}$ and among those who were obese, the average weight lost was $2.3 \mathrm{~kg}$ after $12 \mathrm{mo}$. Waist circumference significantly decreased in all subjects ( $95 \pm 19$ vs. $91 \pm 18 \mathrm{~cm})$ as well as in those who were obese $(101 \pm 26$ vs. $96 \pm 25 \mathrm{~cm}$ ). A control group was not included in this study, but among the 23 subjects that enrolled and waited 6 mo until the treadmill workstation intervention began, body weight remained stable. Although the study design did not use classic components of an experiment, the results suggest that proactive workstations appear to provide increased opportunities for workers to be voluntarily active throughout the day and may promote weight loss, especially for obese individuals.

Cardiovascular and Metabolic Diseases. The study by Koepp el al. (2013) also examined the chronic effects of the treadmill workstation on the cardiovascular system, blood glucose, cholesterol, and triglyceride levels before, during, and after over the one- year intervention. For the entire group $(n=36)$, resting systolic blood pressure decreased slightly but statistically (132 \pm 13 vs. $129 \pm 13 \mathrm{mmHg}, \mathrm{p}<0.05$ ), and HDL increased from baseline ( $55 \pm 20 \mathrm{vs.} 59 \pm 23 \mathrm{mg} / \mathrm{dl}$, $\mathrm{p}<0.05)$. There were no statistically significant changes observed in glucose, LDL, TSH, and triglyceride levels. Overall, positive changes in blood pressure and HDL are promising outcomes for improving the health of individuals, specifically in obese individuals, and reducing the risks of cardiovascular disease, metabolic syndrome, and mortality.

Cognitive Function. A critical objective for an alternative workstation that promotes activity is to not distract workers or disrupt their capacity to be productive. The worker as well as the employer who would invest in active workstations has a vested interest here. On the surface one would assume that reactive, lower intensive workstations are less likely to be intrusive, while proactive workstations could demand mental attention to keep sustained movement, thereby shifting concentration from the subject matter of deskwork. The research is equivocal on this and some evidence actually shows alternative workstations, both reactive and proactive may improve cognitive work productivity, perception of the quality of work, cognitive functioning, and mood after workers switch from a sitting workstation (Dutta, Koepp, Stovitz, Levine, \& Pereira, 2014; Koepp et al., 2013; Larson et al., 2015; Mehta, Shortz, \& Benden, 2015; Roemmich et al., 2014).

Mehta et al. (2015) studied the neurological benefits of standing desks for students. A preliminary finding reported about a 7 to $14 \%$ improvement in cognitive performance in several memory tasks (Mehta et al., 2015). Also, teachers perceived the desks to facilitate student learning without causing a distraction (Mehta et al., 2015). In addition, workers who replaced 
$50 \%$ of their sitting time with standing also increased their sense of well-being and energy, decreased fatigue, and had no impact on work productivity (Dutta et al., 2014). At the beginning of this intervention, participants had pain in the lower-extremities and back as the duration of standing increased. By the second week, these discomforts resolved, and participants were willing to continue using the sit-stand workstation even after the conclusion of the study.

Concerns have been raised about alternative dynamic workstations negatively affecting work productivity. Certainly the concern for personal safety while moving on a treadmill and carrying on intellectual work for one's occupation is reasonable but not necessarily justified. Pedal and treadmill workstations can be set to certain intensities that are comfortable and manageable for the workers. Duration of these activities may also be intermittent throughout the day, such as 10 minutes of pedaling or walking per work hour. In support of this, Elmer y Martin (2014) conducted a study in which participants had to transcribe the Gettysburg Address while sitting stationary at a desk and while pedaling at a desk. This study found that when participants pedaled at a power output of $38 \mathrm{~W}$, there was no statistical difference in the typing time and number of errors compared to sitting (7.7 \pm 1.5 vs. $7.6 \pm 1.6 \mathrm{~min}, 3.3 \pm 4.6$ vs. $3.8 \pm 2.7$ errors). Koepp et al. (2013) also concluded that in a 1-year treadmill workstation study, work performance was unaffected based on supervisor input and weekly surveys. Alternatively, Thompson et al. (2011) showed a decrease in productivity with treadmill workstations. After being trained for 4 hours using the treadmill workstations, the participants were asked to transcribe tapes for 8 hours both while sitting and walking on the treadmill. Accuracy did not differ; however, the speed was $16 \%$ slower while on the treadmill compared to sitting. The potential health benefits are immense for treadmill walking, so it was recommended that greater than 4 hours of training needs to occur to avoid compromising work productivity (Thompson, 2011).

\section{Conclusion}

The detrimental effects of prolonged sitting are well established, and occupational deskwork is clearly part of a sedentary lifestyle that contributes to obesity and other risks of chronic disease. Cautiously, we conclude, based on current research, that alternative workstations may counter the negative effects of extensive periods of sitting at a traditional desk workstation. For elevating metabolic rate, dynamic and active workstations such as treadmill walking or pedaling appear to have a greater impact than static or reactive stations such as standing or sitting on an activity ball; however, the data are limited to a few studies at this point. Additional options need to be investigated. The acute and chronic physiological improvements associated with alternative workstation activities are promising for health benefits particularly if they do not diminish cognitive performance needed for the job. Presently it is not clear whether the benefits originate from muscle contraction or energy expenditure. Regardless, the benefits of alternative workstations should not be misinterpreted to imply that very low intensity activity can be a replacement for planned exercise. Rather they should be an adjunct intervention in the grand scheme of lifestyle strategies for body weight management and optimal health.

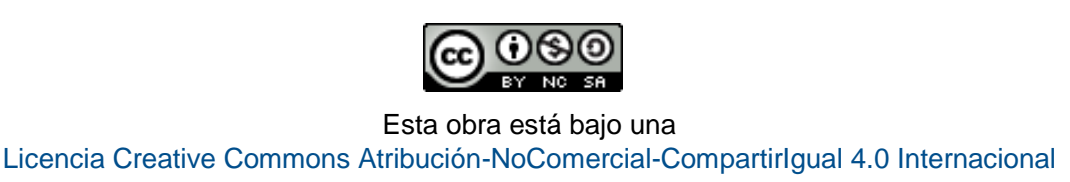




\section{Acknowledgments}

We thank Laura Swan for her diligent review and feedback during the preparation of the manuscript.

\section{References}

Ainsworth, B. E., Haskell, W. L., Whitt, M. C., Irwin, M. L., Swartz, A. M., Strath, S. J., ... Leon, A. S. (2000). Compendium of physical activities: An update of activity codes and MET intensities. Medicine and Science in Sports and Exercise, 32(9), 498-516. doi: http://dx.doi.org/10.1097/00005768-200009001-00009

Altieri, A., Tavani, A., Gallus, S., \& La vecchia, C. (2004). Occupational and leisure time physical activity and the risk of nonfatal acute myocardial infarction in Italy. Annals of Epidemiology, 14(7), 461-466. doi: http://dx.doi.org/10.1016/j.annepidem.2003.11.005

Beasley, R., Raymond, N., Hill, S., Nowitz, M., \& Hughes, R. (2003). eThrombosis: the 21st century variant of venous thromboembolism associated with immobility. European Respiratory Journal, 21(2), 374-376. doi: http://dx.doi.org/10.1183/09031936.03.00039403

Benden, M. E., Zhao, H., Jeffrey, C. E., Wendel, M. L., \& Blake, J. J. (2014). The evaluation of the impact of a stand-biased desk on energy expenditure and physical activity for elementary school students. International Journal of Environmental Research and Public Health, 11(9), 9361-9375. doi: http://doi.org/10.3390/ijerph110909361

Blaak, E.E., Westerterp, K.R., Bar-Or, O., Wouters, L.J.M., \& Saris, W.H.M. (1992). Total energy expenditure and spontaneous activity in relation to training in obese boys. American Journal of Clinical Nutrition, 55, 777-782. Retrieved from https://www.ncbi.nlm.nih.gov/pubmed/1550058

Carr, L. J., Maeda, H., Luther, B., Rider, P., Tucker, S. J., \& Leonhard, C. (2014). Acceptability and effects of a seated active workstation during sedentary work: A proof of concept study. International Journal of Workplace Health Management, 7(1), 2-15. doi: http://dx.doi.org/10.1108/lJWHM-03-2013-0008

Chu, A. H. Y., \& Moy, F. M. (2013). Associations of occupational, transportation, household and leisure-time physical activity patterns with metabolic risk factors among middle-aged adults in a middle-income country. Preventive Medicine, 57(Suppl), 14-17. doi: http://doi.org/10.1016/j.ypmed.2012.12.011

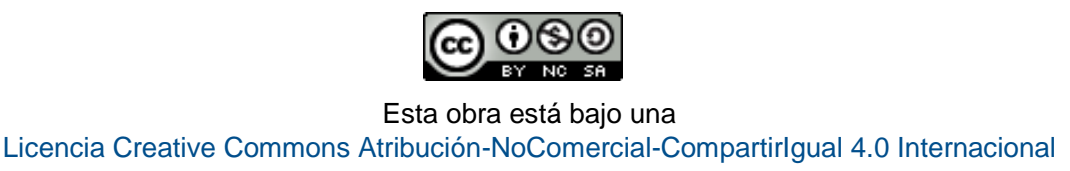


DeLany, J. P., Jakicic, J. M., Lowery, J. B., Hames, K. C., Kelley, D. E., \& Goodpaster, B. H. (2014). African American women exhibit similar adherence to intervention but lose less weight due to lower energy requirements. International Journal of Obesity, 38(9), 11471152. Retrieved from https://www.ncbi.nlm.nih.gov/pubmed/24352292

Dempsey, P. C., Larsen, R. N., Sethi, P., Sacre, J. W., Straznicky, N. E., Cohen, N. D., ... Dunstan, D. W. (2016). Benefits for Type 2 diabetes of interrupting prolonged sitting with brief bouts of light walking or simple resistance activities. Diabetes Research \& Care, 39(6), 964-972. doi: http://doi.org/10.2337/dc15-2336

Dickin, D. C., Surowiec, R. K., \& Wang, H. (2015). Energy expenditure and muscular activation patterns through active sitting on compliant surfaces. Journal of Sport and Health Science. doi: http://doi.org/10.1016/j.jshs.2015.10.004

Drenowatz, C., Grieve, G. L., \& DeMello, M. M. (2015). Change in energy expenditure and physical activity in response to aerobic and resistance exercise programs. SpringerPlus, 4, 798. doi: http://doi.org/10.1186/s40064-015-1594-2

Dunstan, D. W., Howard, B., Healy, G. N., \& Owen, N. (2012a). Too much sitting- A health hazard. Diabetes Research and Clinical Practice, 97(3), 368-376. doi: http://doi.org/10.1016/j.diabres.2012.05.020

Dunstan, D. W., Kingwell, B. A., Larsen, R., Healy, G. N., Cerin, E., Hamilton, M. T., ... Owen, N. (2012b). Breaking up prolonged sitting reduces postprandial glucose and insulin responses. Diabetes Care, 35(5), 976-983. doi: http://doi.org/10.2337/dc11-1931

Dutta, N., Koepp, G. A., Stovitz, S. D., Levine, J. A., \& Pereira, M. A. (2014). Using sit-stand workstations to decrease sedentary time in office workers: A randomized crossover trial. International Journal of Environmental Research and Public Health, 11(7), 6653-6665. doi: http://doi.org/10.3390/ijerph110706653

Elmer, S. J., \& Martin, J. C. (2014). A cycling workstation to facilitate physical activity in office settings. Applied Ergonomics, 45(4), 1240-1246. doi: http://doi.org/10.1016/j.apergo.2014.03.001

Eriksen, D., Rosthøj, S., Burr, H., \& Holtermann, A. (2015). Sedentary work- Associations between five-year changes in occupational sitting time and body mass index. Preventive Medicine, 73, 1-5. doi: http://doi.org/10.1016/j.ypmed.2014.12.038

Faries, M. D. \& Bartholomew, J.B. \& McCallister, T. (2011). Acute effects of stability ball sitting on energy expenditure in the workplace. Medicine and Science in Sports and Exercise, 43(5). doi: http://dx.doi.org/10.1249/01.MSS.0000401664.38661.8e 
Gibbs, B. B., Hergenroeder, A. L., Katzmarzyk, P. T., Lee, I.-M., \& Jakicic, J. M. (2015). Definition, measurement, and health risks associated with sedentary behavior. Medicine and Science in Sports and Exercise, 47(6), 1295-1300. doi: http://doi.org/10.1249/MSS.0000000000000517

Gimeno, D., Elovainio, M., Jokela, M., De Vogli, R., Marmot, M. G., \& Kivimaki, M. (2009). Association between passive jobs and low levels of leisure-time physical activity: The Whitehall II cohort study. Occupational and Environmental Medicine, 66(11), 772-776. doi: http://doi.org/10.1136/oem.2008.045104

Haskell, W. L., Lee, I.-M., Pate, R. R., Powell, K. E., Blair, S. N., Franklin, B. A., ... American Heart Association. (2007). Physical activity and public health: Updated recommendation for adults from the American College of Sports Medicine and the American Heart Association. Circulation, 116(9), 1081-1093. doi: http://doi.org/10.1161/CIRCULATIONAHA.107.185649

Health and Human Services. (2008). Physical activity guidelines for Americans: Be active, healthy, and happy. Retrieved from https://health.gov/paguidelines/pdf/paguide.pdf

Healy, G. N., Dunstan, D. W., Salmon, J., Cerin, E., Shaw, J. E., Zimmet, P. Z., \& Owen, N. (2007). Objectively measured light-intensity physical activity is independently associated with 2-h plasma glucose. Diabetes Care, 30(6), 1384-1389. doi: http://doi.org/10.2337/dc07-0114

Hill, J. O., Melby, C., Johnson, S. L., \& Peters, J. C. (1995). Physical activity and energy requirements. The American Journal of Clinical Nutrition, 62(5), 1059-1066. Retrieved from http://ajcn.nutrition.org/content/62/5/1059S.abstract

Hill, J. O., Wyatt, H. R., Reed, G. W., \& Peters, J. C. (2003). Obesity and the environment: Where do we go from here? Science, 299(5608), 853-855. doi: http://doi.org/10.1126/science.1079857

Howard, B. J., Fraser, S. F., Sethi, P., Cerin, E., Hamilton, M. T., Owen, N., ... Kingwell, B. A. (2013). Impact on hemostatic parameters of interrupting sitting with intermittent activity. Medicine and Science in Sports and Exercise, 45(7), 1285-1291. doi: http://doi.org/10.1249/MSS.0b013e318285f57e

Hu, G., Qiao, Q., Silventoinen, K., Eriksson, J. G., Jousilahti, P., Lindström, J., ... Tuomilehto, J. (2003). Occupational, commuting, and leisure-time physical activity in relation to risk for Type 2 diabetes in middle-aged Finnish men and women. Diabetologia, 46(3), 322-329. Retrieved from http://link.springer.com/article/10.1007/s00125-003-1031-x 
Johannsen, D. L., \& Ravussin, E. (2008). Spontaneous physical activity: Relationship between fidgeting and body weight control. Current Opinion in Endocrinology, Diabetes, and Obesity, 15(5), 409-415. doi: http://doi.org/10.1097/MED.0b013e32830b10bb

Katzmarzyk, P. T., Church, T. S., Craig, C. L., \& Bouchard, C. (2009). Sitting time and mortality from all causes, cardiovascular disease, and cancer. Medicine and Science in Sports and Exercise, 41(5), 998-1005. doi: http://doi.org/10.1249/MSS.0b013e3181930355

Koepp, G. A., Manohar, C. U., McCrady-Spitzer, S. K., Ben-Ner, A., Hamann, D. J., Runge, C. F., \& Levine, J. A. (2013). Treadmill desks: A 1-year prospective trial. Obesity, 21(4), 705711. doi: http://doi.org/10.1002/oby.20121

Larson, M. J., LeCheminant, J. D., Carbine, K., Hill, K. R., Christenson, E., Masterson, T., \& LeCheminant, R. (2015). Slow walking on a treadmill desk does not negatively affect executive abilities: An examination of cognitive control, conflict adaptation, response inhibition, and post-error slowing. Frontiers in Psychology, 6. doi: http://doi.org/10.3389/fpsyg.2015.00723

Lee, I.-M., Shiroma, E. J., Lobelo, F., Puska, P., Blair, S. N., Katzmarzyk, P. T., \& Lancet Physical Activity Series Working Group. (2012). Effect of physical inactivity on major noncommunicable diseases worldwide: An analysis of burden of disease and life expectancy. The Lancet, 380(9838), 219-229. doi: http://doi.org/10.1016/S0140-6736(12)61031-9

Levi, F., Pasche, C., Lucchini, F., \& La Vecchia, C. (1999). Occupational and leisure time physical activity and the risk of breast cancer. European Journal of Cancer, 35(5), 775-778. doi: http://doi.org/10.1016/S0959-8049(99)00051-9

Levine, J. A. (2002). Non-exercise activity thermogenesis (NEAT). Best Practice \& Research. Clinical Endocrinology \& Metabolism, 16(4), 679-702. doi: http://dx.doi.org/10.1053/beem.2002.0227

Levine, J. A. (2005). Measurement of energy expenditure. Public Health Nutrition, 8(7), 11231132. doi: http://dx.doi.org/10.1079/phn2005800

Levine, J. A., \& Miller, J. M. (2007). The energy expenditure of using a "walk-and-work" desk for office workers with obesity. British Journal of Sports Medicine, 41(9), 558-561. doi: http://doi.org/10.1136/bjsm.2006.032755

Lin, T., Courtney, T. K., Lombardi, D. A., \& Verma, S. K. (2015). Association between sedentary work and BMI in a U.S. national longitudinal survey. American Journal of Preventive Medicine, 49(6), 117-123. doi: http://doi.org/10.1016/j.amepre.2015.07.024 
Matthews, C. E., Chen, K. Y., Freedson, P. S., Buchowski, M. S., Beech, B. M., Pate, R. R., \& Troiano, R. P. (2008). Amount of time spent in sedentary behaviors in the United States, 2003-2004. American Journal of Epidemiology, 167(7), 875-881. doi: http://doi.org/10.1093/aje/kwm390

Matthews, C. E., George, S. M., Moore, S. C., Bowles, H. R., Blair, A., Park, Y., ... Schatzkin, A. (2012). Amount of time spent in sedentary behaviors and cause-specific mortality in US adults. The American Journal of Clinical Nutrition, 95(2), 437-445. doi: http://doi.org/10.3945/ajcn.111.019620

Mayo Clinic. (2014). Is sitting the new smoking? New science, old habit. Mayo Clinic Health Letter, 32(10), 4-5. Retrieved from https://www.ncbi.nlm.nih.gov/pubmed/26027033

Mehta, R. K., Shortz, A. E., \& Benden, M. E. (2015). Standing up for learning: A pilot investigation on the neurocognitive benefits of stand-biased school desks. International Journal of Environmental Research and Public Health, 13(1), 59.doi: http://doi.org/10.3390/ijerph13010059

Mummery, W. K., Schofield, G. M., Steele, R., Eakin, E. G., \& Brown, W. J. (2005). Occupational sitting time and overweight and obesity in Australian workers. American Journal of Preventive Medicine, 29(2), 91-97. doi: http://doi.org/10.1016/j.amepre.2005.04.003

Pate, R. R., Pratt, M., Blair, S. N., Haskell, W. L., Macera, C. A., Bouchard, C., ... King, A. C. (1995). Physical activity and public health. A recommendation from the Centers for Disease Control and Prevention and the American College of Sports Medicine. JAMA, 273(5), 402-407. doi: http://dx.doi.org/10.1001/jama.1995.03520290054029

Pate, R. R., O'Neill, J. R., \& Lobelo, F. (2008). The evolving definition of "sedentary." Exercise and Sport Sciences Reviews, 36(4), 173-178. doi: http://doi.org/10.1097/JES.0b013e3181877d1a

Racette, S. B., Schoeller, D. A., Kushner, R. F., \& Neil, K. M. (1995). Exercise enhances dietary compliance during moderate energy restriction in obese women. The American Journal of Clinical Nutrition, 62(2), 345-349. Retrieved from https://www.ncbi.nlm.nih.gov/pubmed/7625341

Ravussin, E., Lillioja, S., Anderson, T. E., Christin, L., \& Bogardus, C. (1986). Determinants of 24hour energy expenditure in man. Methods and results using a respiratory chamber. Journal of Clinical Investigation, 78(6), 1568-1578. http://dx.doi.org/10.1172/JCl112749

Redman, L. M., Heilbronn, L. K., Martin, C. K., de Jonge, L., Williamson, D. A., Delany, J. P., ... Pennington CALERIE Team. (2009). Metabolic and behavioral compensations in response to caloric restriction: Implications for the maintenance of weight loss. PloS One, 4(2). doi: http://doi.org/10.1371/journal.pone.0004377

-19 -

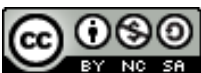

Esta obra está bajo una 
Reiff, C., Marlatt, K., \& Dengel, D. R. (2012). Difference in caloric expenditure in sitting versus standing desks. Journal of Physical Activity \& Health, 9(7), 1009-1011. doi: http://dx.doi.org/10.1123/jpah.9.7.1009

Roemmich, J. (2014). Effect of height adjustable desks on standing time, discomfort, and productivity of office workers with sedentary occupations (37.8). The FASEB Journal, 28(1). Retrieved from http://www.fasebj.org/content/28/1_Supplement/37.8

Ryde, G. C., Brown, H. E., Gilson, N. D., \& Brown, W. J. (2014). Are we chained to our desks? Describing desk-based sitting using a novel measure of occupational sitting. Journal of Physical Activity \& Health, 11(7), 1318-1323. doi: http://doi.org/10.1123/jpah.2012-0480

Sedentary Behaviour Research Network, null. (2012). Letter to the editor: standardized use of the terms "sedentary" and "sedentary behaviours." Applied Physiology, Nutrition, and Metabolism = Physiologie Appliquée, Nutrition Et Métabolisme, 37(3), 540-542. doi: http://doi.org/10.1139/h2012-024

Speck, R.M., Schmitz, K.H. (2011). Energy expenditure comparison: A pilot study of standing instead of sitting at work for obesity prevention. Prevention Medicine, 52(3-4), 283-284. doi: http://dx.doi.org/10.1016/j.ypmed.2011.02.002

Tavani, A., Braga, C., Vecchia, C. L., Conti, E., Filiberti, R., Montella, M., ... Franceschi, S. (1999). Physical activity and risk of cancers of the colon and rectum: An Italian case-control study. British Journal of Cancer, 79, 1912-1916. doi: http://doi.org/10.1038/sj.bjc.6690304

Thivel, D., Chaput, J. P., Adamo, K. B., \& Goldfield, G. S. (2014). Is energy intake altered by a 10-week aerobic exercise intervention in obese adolescents?. Physiology \& Behavior, 135, 130-134. Retrived from https://www.ncbi.nlm.nih.gov/pubmed/24952265

Thompson, W. G., \& Levine, J. A. (2011). Productivity of transcriptionists using a treadmill desk. Work, 40(4), 473-477. Retrieved from https://www.ncbi.nlm.nih.gov/pubmed/22130064

Thorp, A. A., Healy, G. N., Winkler, E., Clark, B. K., Gardiner, P. A., Owen, N., \& Dunstan, D. W. (2012). Prolonged sedentary time and physical activity in workplace and non-work contexts: a cross-sectional study of office, customer service and call centre employees. The International Journal of Behavioral Nutrition and Physical Activity, 9, 128. doi: http://doi.org/10.1186/1479-5868-9-128

Thune, I., Brenn, T., Lund, E., \& Gaard, M. (1997). Physical activity and the risk of breast cancer. The New England Journal of Medicine, 336(18), 1269-1275. http://doi.org/10.1056/NEJM199705013361801 
Tudor-Locke, C., Schuna, J. M., Frensham, L. J., \& Proenca, M. (2014). Changing the way we work: Elevating energy expenditure with workstation alternatives. International Journal of Obesity, 38(6), 755-765. Retrieved from https://www.ncbi.nlm.nih.gov/pubmed/24285335

Van der Ploeg, H. P., Chey, T., Korda, R. J., Banks, E., \& Bauman, A. (2012). Sitting time and allcause mortality risk in 222497 Australian adults. Archives of Internal Medicine, 172(6), 494-500. doi: http://doi.org/10.1001/archinternmed.2011.2174

Warren, T. Y., Barry, V., Hooker, S. P., Sui, X., Church, T. S., \& Blair, S. N. (2010). Sedentary behaviors increase risk of cardiovascular disease mortality in men. Medicine and Science in Sports and Exercise, 42(5), 879-885. doi: http://doi.org/10.1249/MSS.0b013e3181c3aa7e

Willis, E. A., Herrmann, S. D., Honas, J. J., Lee, J., Donnelly, J. E., \& Washburn, R. A. (2014). Nonexercise energy expenditure and physical activity in the Midwest exercise trial 2. Medicine and Science in Sports and Exercise, 46(12), 2286-2294. doi: http://doi.org/10.1249/MSS.0000000000000354

Wright, T. G., Dawson, B., Jalleh, G., \& Guelfi, K. J. (2015). Influence of hormonal profile on resting metabolic rate in normal, overweight and obese individuals. Annals of Nutrition \& Metabolism, 66(2-3), 162-167. doi: http://doi.org/10.1159/000382080

Zderic, T. W., \& Hamilton, M. T. (2012). Identification of hemostatic genes expressed in human and rat leg muscles and a novel gene (LPP1/PAP2A) suppressed during prolonged physical inactivity (sitting). Lipids in Health and Disease, 11, 137. doi: http://doi.org/10.1186/1476-511X-11-137

Contribution: A- Funding, B- Study design, C- Data collection, D- Statistical analysis and interpretation of results, E- Manuscript preparation. 